\title{
Acacia mangium Willd: benefits and threats associated with its increasing use around the world
}

\author{
Lydie-Stella Koutika $^{1 *}$ and David M. Richardson²
}

\begin{abstract}
Background: Acacia mangium, a fast-growing tree native to parts of Indonesia, Papua New Guinea and Australia, has been cultivated outside its native environment and introduced into humid tropical lowland regions of Asia, South America and Africa over the last few decades. It is a multipurpose tree used in agroforestry, forestry and for restoration of degraded lands. It is also highly invasive in many regions where it has been introduced outside its native range. This paper reviews evidence of its obvious benefits and its negative impacts on biodiversity.

Methods: A literature review on Australian acacias and especially on A. mangium was undertaken to highlight both benefits and threats associated with their increasing worldwide use outside their native ranges.

Results: Through $\mathrm{N}_{2}$ fixed from the atmosphere, A. mangium improves soil fertility, especially by increasing $\mathrm{N}$ status and soil $\mathrm{C}$ accretion when introduced to $\mathrm{N}$-limited areas; it thus has the potential to restore nutrient cycling in degraded systems. No studies have, however, been done to assess the effectiveness of A. mangium in restoring biodiversity of degraded lands. Most Australian acacias have traits that facilitate invasiveness, and 23 species have been recorded as invasive to date. A. mangium has been reported as invasive in Asia, Indonesia, Pacific Islands, Indian Ocean Islands, southern Africa and Brazil. Research on other invasive Australian acacias in several parts of the world has elucidated the types of impacts that are likely in different types of ecosystems and key options for mitigating impacts.

Conclusions: A. mangium has the potential to restore nutrient cycling in degraded systems, but is highly invasive wherever it is planted. Many parts of the world have a large invasion debt for this species. Experience with other invasive acacias around the world suggests a suite of interventions that could be used to reduce invasions and mitigate impacts. Careful risk assessments should be undertaken prior to any new plantings of this species.
\end{abstract}

Keywords: Biodiversity, Biological invasions, C sequestration, Soil N status, Tree invasions

\section{Background}

Due to their diverse uses, tropical Australian acacias are widely planted around the world - in Asia where they were first introduced (Midgley and Turnbull 2003; Inagaki et al. 2011; Richardson et al. 2011), Africa (Bernhard-Reversat 1993; Tassin et al. 2012; Dubliez et al. 2018) and South America (Franco and de Faria, 1997; Chaer et al. 2011; Attias et al. 2013). They are used in agriculture, forestry and agroforestry to improve soil fertility (especially

\footnotetext{
* Correspondence: Is_koutika@yahoo.com; https://orcid.org/0000-0001-82233032

${ }^{1}$ CRDPI, Centre de Recherche sur la Durabilité et la Productivité des Plantations Industrielles, BP 1291 Pointe-Noire, Republic of the Congo Full list of author information is available at the end of the article
}

soil nitrogen), to sequester carbon and potentially to restore nutrient cycling in degraded lands and forests, but also for commercial forestry, for ornamental purposes, and to supply wood and charcoal (Bernhard-Reversat 1993; Franco et al. 1994; Parrotta and Knowles, 1999; Fuentes-Ramírez et al. 2011; Bouillet et al. 2013; Sitters et al. 2013; Permadi et al., 2017). Forest productivity or crop yields usually increase on $\mathrm{N}$-limited sites in the presence of N-fixing species (NFS) such as Australian acacias (Binkley 1992; Khanna 1998; Bouillet et al. 2013; Nambiar and Harwood 2014; Paula et al. 2015; Dubliez et al. 2018), as does soil N status (Sanginga et al. 1986; Binkley 1992; Parrotta, 1999; Kaye et al. 2000; Resh et al. 2002; Ludwig 
et al. 2004; Hagos and Smit 2005; Sitters et al. 2013). Most Australian acacias have the capacity to sequester $C$ in both soil and biota which also addresses goals associated with climate-change mitigation (Binkley 1992; Kaye et al. 2000; Resh et al. 2002; Lee et al. 2015; Forrester et al. 2013), though soil C storage may not occur in some cases (Voigtlaender et al. 2012; Oelofse et al. 2016).

Most Australian acacias have traits associated with invasiveness. Twenty-three species have been recorded as invasive to date, and some are major invasive species in many geographical areas (Richardson and Rejmánek 2011; Gibson et al. 2011; Rejmánek and Richardson 2013; Richardson et al. 2015). In documenting the global biogeography and invasion ecology of Australian acacias, Richardson et al. (2011) showed that all species that have been widely planted for forestry or other uses have become invasive. Whether an alien species becomes invasive depends on many factors, including life-history traits and the extent, level, and duration of species usage in the new environment. Considerable work has been done in this regard on Australian acacias. Interactions between traits, human usage, and residence time explain the extent of invasiveness for acacias (Castro-Díez et al. 2011). There is usually a long time lag between introduction and planting and the start of invasive spread; this results in a substantial 'invasion debt' in many areas where the widespread planting of alien species has occurred recently (Rouget et al. 2016).

A. mangium, one of the Australian acacias that is widely planted in many parts of the world, has clear benefits in agricultural, agroforestry and forestry ecosystems (Bernhard-Reversat 1993; Franco et al. 1994; Parrotta and Knowles, 1999; Richardson et al. 2004; Kull et al. 2011; Epron et al. 2013). Key reasons for the widespread planting of $A$. mangium, in commercial monoculture plantations or in mixed plantings with other tree species or crops in areas with infertile soils, are its capacity to improve soil fertility (Wang et al. 2010; Forrester et al. 2013; Koutika et al. 2014; Machado et al. 2017; Tchichelle et al. 2017), change the soil faunal, microbial and bacterial communities (Bernhard-Reversat 1993; Bini et al. 2012, 2013; Huang et al. 2014; Pereira et al. 2017), and to stimulate crop or tree growth and forest productivity (Bouillet et al. 2013; Epron et al. 2013; Paula et al. 2015). The species is considered useful for these purposes due to the enhanced nutrient cycling, higher nutrient availability and microbial activities that accrue from its presence (Khanna 1998; Bini et al. 2012; Rachid et al. 2013; Santos et al., 2017a, b). Introduction of $A$. mangium to agricultural, agroforestry or large open areas is, however, increasingly being shown to trigger major biological invasions. The number of publications documenting the invasive spread of $A$. mangium from planting sites is increasing rapidly; the species is currently recorded as an invasive species in Asia, Indonesia, southern Africa and South America (Richardson and Rejmánek 2011; Ismael and Metali 2014; Aguiar et al. 2014; Meira-Neto et al. 2018; Souza et al. 2018). Such invasions are reducing the overall benefit from using the species and is creating conflicts of interest between (agro) foresters on the one hand and conservationists and natural resource managers on the other. Such conflicts are arising in many temperate regions of the world where other Australian Acacia species (and other legume trees) have been planted outside their native range. Management initiatives are underway in many areas to reduce such conflicts (e.g. Kull and Rangan 2008; Dickie et al. 2014; van Wilgen and Richardson 2014; Shackleton et al. 2018 and references therein).

Australian acacias are favoured for planting because of their high adaptability; climatic modelling shows that roughly a third of the world's land areas are suitable for growth of Australian acacias (Richardson et al. 2011). The largest area of plantations of tropical Australian acacias is in South East Asia where plantings cover about 2 Mha (Midgley and Turnbull 2003; Arisman and Hardiyanto 2006; Kull and Rangan 2008). A. mangium Willd., a large tree which can reach $30 \mathrm{~m}$ in height, is native to parts of Indonesia, Papua New Guinea and Australia. The species produces many flowers and is mainly pollinated by bees (Midgley and Turnbull 2003). It grows in coastal, tropical lowlands (at altitudes below $300 \mathrm{~m}$ ) and in a range of forest types (rainforests to open forests), but also in woodlands disturbed by fire (Midgley and Turnbull 2003). The natural distribution of $A$. mangium overlaps with the warm and hot tropical climatic zones where the temperatures are high and equable throughout the year, with the mean maximum temperature during the hottest month between $31^{\circ} \mathrm{C}$ and $34^{\circ} \mathrm{C}$ and the mean minimum temperature during the coolest month between $15^{\circ} \mathrm{C}$ and $22^{\circ} \mathrm{C}$ (Otsamo et al. 1997; Midgley and Turnbull 2003). Mean annual rainfall across its natural range is between 1500 and $3000 \mathrm{~mm}$, with summer (January to March) being the wettest period. This fast-growing species prefers well-drained soils of moderate to low fertility (Franco et al. 1994; Cole et al. 1996; Bouillet et al. 2013; Aguiar et al. 2014). Extended dry season and sandy and nutrientpoor soils outside its native range may, however, trigger growth during the first year (Koutika et al. 2018). Like many acacia species, A. mangium is adapted to acidic soils, and grows in soils with pH below 4 (Franco and de Faria, 1997; Midgley and Turnbull 2003).

This paper reviews the benefits and threats of $A$. mangium in areas where it is planted outside its native range, and discusses whether it is feasible to promote planting of the species to encourage the benefits it provides while reducing current and potential future negative impacts due to invasiveness. 


\section{Methods}

\section{Literature review}

Using keywords associated with 'Australian acacias' and ' $A$. mangium' we undertook a detailed review of peer-reviewed papers, books, book chapters, conference proceedings, online publications and the grey literature. We used Google, Google Scholar, Web of Science, and the databases of research institutions, notably EMBRAPA (Brazilian Agricultural Research Corporation), CIMMYT (The International Maize and Wheat Improvement Center), Université de Lorraine (France), and the Centre for Invasion Biology (Stellenbosch University) to source information on the benefits and impacts associated with the use of Australian acacias, and particularly A. mangium, outside their native ranges.

\section{Acacia mangium and its changing global distribution}

A. mangium is widely used in commercial plantations to provide products such as pulp, firewood, charcoal, construction material; it is also used for soil protection and ecological restoration purposes and as a food source for bees (Awang and Taylor 1993; Franco and de Faria, 1997; Otsamo et al. 1997; Midgley and Turnbull 2003; Eyles et al. 2008; Kull and Rangan 2008; Coetzee et al. 2011; Hai et al. 2015). Key life-history traits of the species are its rapid growth, prolific production of hard -coated, heat-tolerant and long-lived seeds with the capacity for long dormancy and long-distance dispersal by birds (Awang and Taylor 1993; Franco et al. 1994; Gibson et al. 2011; Low 2012). A. mangium has been widely cultivated outside its native range in the last century, mainly in the humid tropical lowlands of Asia, South America and Africa (Bernhard-Reversat 1993; Otsamo et al. 1997; Franco and de Faria, 1997; Kull et al. 2007; Hai et al. 2015; Oelofse et al. 2016, Table 1). The species was first introduced to Malaysia in 1966 where it was initially planted for firebreaks and to protect pine plantations, but its rapid growth suggested potential for wood

Table 1 First introduction of Acacia mangium and current levels of planting in some countries around the world. Seeds of A. mangium were also dispatched from Australian Tree Seed Centre to the following countries for which detailed planting details are not available (decade that seeds were first dispatched in brackets): Cambodia (1980s), Central African Republic (2000s), Colombia (1980s), Cote d'Ivoire (1980s), India (1980s), Laos (1980s), Mexico (1980s), Mozambique (1980s), Myanmar (1980s), Sri Lanka (1980s), Tanzania (1980s), Thailand (1980s), Uganda (1980s) and Venezuela (1980s)(Australian Tree Seed Centre, unpublished data)

\begin{tabular}{|c|c|c|c|c|}
\hline Countries / Time & First introduction \& purpose(s) & $\begin{array}{l}\text { Initial planted } \\
\text { areas }\end{array}$ & $\begin{array}{l}\text { Current level } \\
\text { of plantings }\end{array}$ & Key references \\
\hline \multicolumn{5}{|l|}{ Asia } \\
\hline China & 1979 & NA & NA & Yang et al. 2009 \\
\hline Indonesia & Native (eastern part) 1960s & NA & $\begin{array}{l}\text { 300,000-500,000 ha } \\
(2013)\end{array}$ & $\begin{array}{l}\text { Midgley and Turnbull 2003; Nambiar \& } \\
\text { Harwood 2014; Nambiar et al. } 2018\end{array}$ \\
\hline Malaysia & 1966, Forestry\& restoration & $\begin{array}{l}15,000 \text { ha } \\
\text { degraded } \\
\text { lands }\end{array}$ & $\begin{array}{l}250,000 \text { ha } \\
(2013)\end{array}$ & $\begin{array}{l}\text { National Research Council 1983; Midgley } \\
\text { and Turnbull 2003; } \\
\text { Nambiar \& Harwood 2014; } \\
\text { Nambiar et al. } 2018\end{array}$ \\
\hline Philippines & 1977 & NA & NA & National Research Council 1983 \\
\hline Vietnam & $\begin{array}{l}\text { 1960s (southern part), 1980s (northern part), Genetic } \\
\text { improvement, reforestation, reclamation }\end{array}$ & 580,000 ha & $\begin{array}{l}600,000 \text { ha } \\
(2013)\end{array}$ & $\begin{array}{l}\text { Kull et al. 2011; Nambiar et al. 2014; } \\
\text { Nambiar \& Harwood 2014; } \\
\text { Frey et al. } 2018\end{array}$ \\
\hline \multicolumn{5}{|l|}{ Africa } \\
\hline Cameroon & 1980, Planting program & NA & NA & National Research Council 1983 \\
\hline DR Congo & 1980s, Agroforestry & NA & NA & Tassin et al. 2012 \\
\hline Kenya & 1980s & NA & NA & $\begin{array}{l}\text { Kenya Forestry Research Organization } \\
\text { (KEFRI) }\end{array}$ \\
\hline $\begin{array}{l}\text { Republic of } \\
\text { the Congo }\end{array}$ & 1990s, Experimental plantations & NA & NA & Bernhard-Reversat 1993 \\
\hline \multicolumn{5}{|l|}{ America } \\
\hline $\begin{array}{l}\text { Brazil } \\
\text { (Roraima) }\end{array}$ & 1990s, Commercial forestry & 30,000 ha & NA & Souza et al. 2018 \\
\hline Costa Rica & 1980, Planting program & NA & NA & National Research Council 1983 \\
\hline $\begin{array}{l}\text { Dominican } \\
\text { Republic }\end{array}$ & 1980s, Social forestry & NA & NA & Kull et al. 2011 \\
\hline Hawaii & 1979, Planting program & NA & NA & National Research Council 1983 \\
\hline
\end{tabular}


production (Midgley and Turnbull 2003). Kull and Rangan (2008) reported that in the 2000s, both Malaysia and Indonesia had nearly 850,000 ha of commercial plantations of A. mangium. In South America, A. mangium has been introduced for different purposes. Commercial cultivation for pulpwood production and tannin and plantings for the reclamation of degraded lands were main reasons for the introduction of $A$. mangium to Brazil (Franco and de Faria, 1997; Attias et al. 2013), while in northeastern Costa Rica the species has been used mainly for restoration plantations (Chazdon 2008).

In South East Asia, species such as A. mangium and A. auriculiformis are used mainly for solid wood production and short-rotation fibre (Midgley and Turnbull 2003). Due to their large canopies and ability to increase soil $\mathrm{N}$ and soil organic matter (SOM), to improve conditions for photosynthesis, and to buffer air and soil temperatures, $A$. auriculiformis and A. mangium have been widely planted in degraded areas to serve as nurse trees for understorey plants in South China (Yang et al. 2009). In Central Africa, A. auriculiformis and A. mangium have been planted as part of Project Makala (http:// makala.cirad.fr/le_projet_makala) for fuel and wood energy e.g., in DR Congo and the Republic of the Congo. Both species were also planted for agroforestry and forestry in the two countries. A. auriculiformis is valued by farmers for both agricultural and wood-energy production in agroforestry or forestry systems in DR Congo (Kasongo et al. 2009; Shure et al. 2010; Dubliez et al. 2018), while A. mangium is mainly used to sustain eucalypt plantations to provide pulp, fuel and wood energy in the Congolese coastal plains of the Republic of the Congo (Shure et al. 2010; Bouillet et al. 2013; Epron et al. 2013; Tchichelle et al. 2017).

\section{History and extent of invasiveness of $A$. mangium}

In some countries, $A$. mangium is considered an invasive tree species (Richardson and Rejmánek 2011; Low 2012; Rejmánek and Richardson 2013; Attias et al. 2013; Aguiar et al. 2014; Sampaio and Schmidt 2013; Richardson et al. 2015; Witt 2017; Souza et al. 2018). We could find no statistics on the extent of invasions or the area invaded in different regions. In northeastern Roraima State, Brazilian Amazonia, invasions commenced within a decade of the establishment of large plantations, and invading plants were recorded up to $900 \mathrm{~m}$ from the plantation edge (Aguiar et al. 2014). Table 1 shows that introductions and major plantings of $A$. mangium are recent in most parts of the world; experience in South Africa has shown that major invasions of Australian acacias typically occur only several decades after major plantings began (Richardson et al. 2015). This means that most of the countries mentioned in Table 1 have a major invasion debt (Rouget et al. 2016) for A. mangium and that large-scale invasions are likely to occur over the next few decades.

\section{Benefits of using $A$. mangium for ecosystems and the environment \\ Improving soil nitrogen status}

Nitrogen-fixing species (NFS) have the ability to improve soil $\mathrm{N}$ status. For example, Leucaena leucocephala (Lam.) de Wit, a NFS, provided more than $500 \mathrm{~kg}$ of N ha. ${ }^{-1}$ (Sanginga et al. 1986). Parrotta (1999) reported higher $\mathrm{N}$ accretion in L. leucocephala stands relative to pure eucalypt stands or when grown in association with another NFS, Casuarina equisetifolia L. Acacia auriculiformis, established as fallow in the mixed crop food systems on sandy arenosols in DR Congo, increases soil $\mathrm{N}$ (Kasongo et al. 2009). A. auriculiformis and A. mangium were planted to serve as nurse trees for understorey plants in degraded soils in South China (Yang et al. 2009). Higher soil N status was found in A. mangium relative to $A$. auriculiformis - a total soil nitrogen of $0.103 \pm 0.02 \%$ vs. $0.092 \pm 0.01 \%$ and a hydrolysed nitrogen of $105.7 \pm 16.9 \mathrm{mg} \cdot \mathrm{kg}^{-1}$ vs $89.3 \pm 3.78 \mathrm{mg} \cdot \mathrm{kg}^{-1}$ (Table 2). Soil $\mathrm{N}$ status improved in the pure A. mangium relative to pure eucalypt stands with the cumulative net production of mineral $\mathrm{N}$ over the two first years in the second rotation of 7 years i.e., $343 \mathrm{~kg} \cdot \mathrm{ha}^{-1}$ in acacia and only $189 \mathrm{~kg} \cdot \mathrm{ha}^{-1}$ in eucalypt stands in the Congolese coastal plains (Tchichelle et al. 2017). This has been confirmed by the $30 \%$ higher $\mathrm{N}$ concentration in coarse particulate organic matter (POM, 4000-250 $\mu \mathrm{m})$, an active part of soil organic matter, in pure A. mangium stands compared to pure eucalypt stands at year 2 of the second rotation (Koutika et al. 2017). These findings are in accordance with the reduction in $\mathrm{N}$-limitation to growth shown by an increase in N: P ratio of eucalypt leaves from $9.4 \pm 0.5$ (end of the 7 first year rotation) to $13.1 \pm 0.6$ (year 2 of the second rotation) (Koutika et al. 2016), and the improvement in soil $\mathrm{N}$ status of afforested stands containing acacias compared to natural savannas (Koutika and Mareschal 2017).

\section{Potential to restore degraded lands}

We found no published evidence to support the contention that the planting of Australian acacias aids in restoring biodiversity levels or the conservation value of degraded ecosystems. Several Australian acacias do, however, have the potential to restore elements of nutrient cycling in degraded ecosystems (Franco and de Faria, 1997; Yang et al. 2009; Sang et al. 2013; Machado et al. 2017). NFS, including A. mangium, have the potential to rehabilitate degraded lands (Otsamo et al. 1997; Wang et al. 2010; Richardson et al. 2015; Permadi et al., 2017, Table 2), unmanaged secondary forests (Sang et al. 2013) and understorey plants (Yang et al. 2009). The ability to 
Table 2 Benefits of planting Acacia mangium in terms of land restoration, C sequestration, soil fertility and tree production in different ecosystems

\begin{tabular}{|c|c|c|c|c|c|c|c|c|c|}
\hline \multirow{2}{*}{$\begin{array}{l}\text { Original ecosystem / } \\
\text { habitat }\end{array}$} & \multirow{2}{*}{$\begin{array}{l}\text { Current } \\
\text { ecosystem }\end{array}$} & \multirow[t]{2}{*}{ Country } & \multirow[t]{2}{*}{ Soil type } & \multicolumn{4}{|l|}{ Soil fertility } & \multirow{2}{*}{$\begin{array}{l}\text { Tree } \\
\text { productivity }\end{array}$} & \multirow[t]{2}{*}{ Reference } \\
\hline & & & & Nitrogen status & $\begin{array}{l}\text { Phosphorus } \\
\text { status }\end{array}$ & $\begin{array}{l}\text { Carbon } \\
\text { status }\end{array}$ & $\begin{array}{l}\text { Soil fauna/ } \\
\text { microbial } \\
\text { status }\end{array}$ & & \\
\hline Savannas & $\begin{array}{l}\text { Acacia } \\
\text { plantations }\end{array}$ & $\begin{array}{l}\text { Republic } \\
\text { of } \\
\text { Congo }\end{array}$ & Arenosols & NA & NA & NA & $\begin{array}{l}\text { Higher } \\
\text { activity of } \\
\text { macroar- } \\
\text { thropods, } \\
\text { incl. } \\
\text { Cockroaches }\end{array}$ & NA & $\begin{array}{l}\text { Bernhard- } \\
\text { Reversat } \\
1993\end{array}$ \\
\hline $\begin{array}{l}\text { Degraded } \\
\text { areas }\end{array}$ & $\begin{array}{l}\text { Revegetating } \\
\text { tailing tanks }\end{array}$ & Brazil & $\begin{array}{l}\text { Tropical } \\
\text { soils }\end{array}$ & $\begin{array}{l}\text { Increased } \\
(190 \mathrm{~kg} \\
\left.\text { of } \mathrm{N} \mathrm{ha}^{-1} \cdot \mathrm{y}^{-1}\right)\end{array}$ & NA & Increased & NA & NA & $\begin{array}{l}\text { Franco } \\
\text { and de } \\
\text { Faria, } 1997\end{array}$ \\
\hline $\begin{array}{l}\text { Eucalyptus } \\
\text { siebiri }\end{array}$ & $\begin{array}{l}\text { Mixed-species } \\
\text { plantations }\end{array}$ & Australia & $\begin{array}{l}\text { Sandy } \\
\text { clay loam }\end{array}$ & + & NA & $\begin{array}{l}\text { Increased } \\
\text { soil C }\end{array}$ & NA & Increased & $\begin{array}{l}\text { Forrester } \\
\text { et al. } \\
2013\end{array}$ \\
\hline $\begin{array}{l}\text { Pinus } \\
\text { massoniana } \\
\text { plantation }\end{array}$ & $\begin{array}{l}\text { Eucalypt and } \\
\text { acacia } \\
\text { plantations } \\
\text { (1978) }\end{array}$ & China & Oxisol & $\begin{array}{l}\text { Increase in } \\
\mathrm{NH}_{4}-\mathrm{N}, \\
\mathrm{NO}_{3}-\mathrm{N}, \\
\text { and total } \\
\mathrm{N} \text { in the } \\
\text { mixed } \\
\text { species } \\
\text { plantations }\end{array}$ & NA & $\begin{array}{l}\text { Increase in } \\
\text { total C }\end{array}$ & $\begin{array}{l}\text { Changes in } \\
\text { microbial } \\
\text { communities }\end{array}$ & NA & $\begin{array}{l}\text { Huang } \\
\text { et al. } 2014\end{array}$ \\
\hline Plantations & $\begin{array}{l}\text { Mixed- } \\
\text { species } \\
\text { plantations } \\
\text { with } A \text {. } \\
\text { mangium }\end{array}$ & Malaysia & $\begin{array}{l}\text { Haplic } \\
\text { Alisols }\end{array}$ & $\begin{array}{l}\text { More N } \\
\text { in the } \\
\text { litterfall }\end{array}$ & $\begin{array}{l}\text { Less } P \text { in the } \\
\text { litterfall }\end{array}$ & NA & NA & NA & $\begin{array}{l}\text { Inagaki } \\
\text { et al. } 2011\end{array}$ \\
\hline $\begin{array}{l}\text { Savannas/ } \\
\text { Eucalypt } \\
\text { plantations } \\
\text { (1984) }\end{array}$ & $\begin{array}{l}\text { Eucalypt and } \\
\text { acacia } \\
\text { plantations } \\
\text { (2004) }\end{array}$ & $\begin{array}{l}\text { Republic } \\
\text { of } \\
\text { Congo }\end{array}$ & Arenosols & $\begin{array}{l}\text { Increase in } \\
\mathrm{N} \\
\text { stocks } \\
(0-0.25 \mathrm{~m}) / \\
\text { Increase in } \\
\mathrm{N} \text { contents } \\
\text { of coarse } \\
\mathrm{POM} \\
(4-0.25 \mathrm{~mm}) \\
\text { Increase in } \\
\mathrm{N} \text { mineralization } \\
\text { in pure acacia }\end{array}$ & $\begin{array}{l}\text { Decrease in } \\
\text { available P } \\
\text { in the } \\
\text { mixed } \\
\text { species } \\
\text { stands (0- } \\
0.15 \mathrm{~m} \text { ) }\end{array}$ & $\begin{array}{l}\text { Increase in C } \\
\text { stocks } \\
(0-0.25 \mathrm{~m})\end{array}$ & NA & $\begin{array}{l}\text { Eucalypt } \\
\text { benefits } \\
\text { from } \mathrm{N}_{2} \\
\text { fixed by } \\
\text { acacia }\end{array}$ & $\begin{array}{l}\text { Koutika } \\
\text { et al. 2014; } \\
\text { Koutika } \\
\text { et al. 2017; } \\
\text { Epron et al. } \\
\text { 2013; } \\
\text { Tchichelle } \\
\text { et al. } 2017\end{array}$ \\
\hline $\begin{array}{l}\text { Degraded } \\
\text { lands with } \\
\text { low fertility }\end{array}$ & $\begin{array}{l}\text { A. mangium } \\
\text { plantations }\end{array}$ & Malaysia & & NA & NA & Increased & NA & Increased & $\begin{array}{l}\text { Lee et al. } \\
2015\end{array}$ \\
\hline Eucalyptus & $\begin{array}{l}\text { Eucalypt and } \\
\text { acacia } \\
\text { plantations }\end{array}$ & Brazil & Ferralsol & - & - & - & $\begin{array}{l}\text { Higher activity } \\
\text { of microbial } \\
\text { and bacterial } \\
\text { communities }\end{array}$ & - & $\begin{array}{l}\text { Pereira } \\
\text { et al. 2017, } \\
\text { Pereira } \\
\text { et al. } 2018\end{array}$ \\
\hline $\begin{array}{l}\text { Degraded } \\
\text { tropical } \\
\text { lands }\end{array}$ & A. mangium & Vietnam & - & Increased & NA & NA & NA & NA & $\begin{array}{l}\text { Sang et al. } \\
2013\end{array}$ \\
\hline $\begin{array}{l}\text { Fallow for } \\
\text { more than } \\
15 \text { years }\end{array}$ & $\begin{array}{l}\text { Eucalypt and } \\
\text { acacia } \\
\text { plantations }\end{array}$ & Brazil & $\begin{array}{l}\text { Haplic } \\
\text { Planosol }\end{array}$ & $\begin{array}{l}\text { More } \mathrm{N} \text { in } \\
\text { the litterfall } \\
\text { of acacia vs } \\
\text { eucalypt }\end{array}$ & $\begin{array}{l}\text { More } P \text { in } \\
\text { the litterfall } \\
\text { of eucalypt } \\
\text { vs acacia }\end{array}$ & NA & $\begin{array}{l}\text { NA } \\
\text { High } \\
\text { microbial } \\
\text { activity }\end{array}$ & $\begin{array}{l}\text { Eucalypt } \\
\text { benefits } \\
\text { from } \mathrm{N}_{2} \\
\text { fixed by } \\
\text { acacia }\end{array}$ & $\begin{array}{l}\text { Santos } \\
\text { et al. } \\
\text { 2017a; } \\
\text { Santos } \\
\text { et al. } \\
\text { 2017b; }\end{array}$ \\
\hline $\begin{array}{l}\text { Disturbed } \\
\text { evergreen } \\
\text { broadleaved } \\
\text { forest }\end{array}$ & $\begin{array}{l}\text { Restored } \\
\text { forest with } \\
\text { A. mangium } \\
\text { and } A \text {. } \\
\text { auriculiformis }\end{array}$ & China & Red soil & + & NA & + & + & $\begin{array}{l}\text { Good nurse } \\
\text { plants for } \\
\text { understory } \\
\text { species }\end{array}$ & $\begin{array}{l}\text { Yang et al. } \\
2009\end{array}$ \\
\hline
\end{tabular}


Table 2 Benefits of planting Acacia mangium in terms of land restoration, C sequestration, soil fertility and tree production in different ecosystems (Continued)

\begin{tabular}{|c|c|c|c|c|c|c|c|c|c|}
\hline \multirow{2}{*}{$\begin{array}{l}\text { Original ecosystem / } \\
\text { habitat }\end{array}$} & \multirow{2}{*}{$\begin{array}{l}\text { Current } \\
\text { ecosystem }\end{array}$} & \multirow[t]{2}{*}{ Country } & \multirow[t]{2}{*}{ Soil type } & \multicolumn{4}{|l|}{ Soil fertility } & \multirow{2}{*}{$\begin{array}{l}\text { Tree } \\
\text { productivity }\end{array}$} & \multirow[t]{2}{*}{ Reference } \\
\hline & & & & Nitrogen status & $\begin{array}{l}\text { Phosphorus } \\
\text { status }\end{array}$ & $\begin{array}{l}\text { Carbon } \\
\text { status }\end{array}$ & $\begin{array}{l}\text { Soil fauna/ } \\
\text { microbial } \\
\text { status }\end{array}$ & & \\
\hline $\begin{array}{l}\text { Degraded } \\
\text { lands }\end{array}$ & $\begin{array}{l}\text { Mixed } \\
\text { species } \\
\text { plantations }\end{array}$ & China & - & $\begin{array}{l}20 \%-50 \% \\
\text { higher } \mathrm{N} \text { than } \\
\text { non-N-fixers } \\
\text { counterpart }\end{array}$ & - & $\begin{array}{l}40 \%-50 \% \\
\text { higher } \\
\text { SOM than } \\
\text { non-N- } \\
\text { fixers counter- } \\
\text { part }\end{array}$ & NA & $\begin{array}{l}\text { Land } \\
\text { restoration }\end{array}$ & $\begin{array}{l}\text { Wang et al. } \\
2010\end{array}$ \\
\hline
\end{tabular}

form symbioses with nodulating $\mathrm{N}_{2}$-fixing bacteria and arbuscular mycorrhizal fungi of leguminous trees is key in this regard (Chaer et al. 2011). Franco and de Faria (1997) showed that A. mangium may provide around 12 tons of dry litter and $190 \mathrm{~kg}$ of $\mathrm{N} \mathrm{ha}^{-1} \cdot \mathrm{y}^{-1}$ to restore degraded lands in Brazil. The effects of monospecific plantations of A. mangium, Dipteryx odorata, Jacaranda copaia, Parkia decussata, and Swietenia macrophylla established in pasture areas on soil chemical properties were evaluated in the Brazilian state of Amazonas (Machado et al. 2017). These authors advised planting A. mangium and $S$. macrophylla to rehabilitate degraded areas because of their important role in cycling of $\mathrm{N}$ and $\mathrm{P}$, the most limiting nutrients in the soil for tropical forest productivity. Re-establishment of soil $\mathrm{C}$ and $\mathrm{N}$ cycling processes were reported after planting of $A$. auricu liformis and A. mangium in southern China (Wang et al. 2010). For economic reasons (e.g., low cost of reforestation, the positive correlation between $\mathrm{C}$ sequestration, $\mathrm{N}$ and $\mathrm{P}$ amounts and aboveground biomass production) A. mangium is considered superior to Eucalyptus urophylla across edaphic and climate gradients in Vietnam (Sang et al. 2013).

\section{Enhancing carbon sequestration}

NFS often have beneficial impacts on climate change mitigation in reducing atmospheric $\mathrm{CO}_{2}$ by sequestering C in both soil and biota (Binkley 1992; Chen et al. 2011; Sang et al. 2013). In most cases, carbon sequestration in soil and biomass occurs when NFS are introduced to agricultural, agroforestry, and forestry systems (Binkley 1992; Resh et al. 2002; Kasongo et al. 2009; Chen et al. 2011; Forrester et al. 2013; Sang et al. 2013; Dubliez et al. 2018). C sequestration occurred in both soil and aboveground biomass in $A$. mangium plantations in Malaysia, with higher soil $C$ stocks, ranging between $52.2 \%$ to $87.5 \%$ of the total C (soil and biomass) stocks, while the overall $C$ stocks were $74.9,89.9$ and 138.9 t.ha ${ }^{-1}$ for 1-, 3-, and 5-year-old stands (Lee et al. 2015). $\mathrm{C}$ accretion has been reported down to $25 \mathrm{~cm}$ in the mixed-species (50\% acacia and 50\% eucalypt) stands $\left(17.8 \pm 0.7 \mathrm{t}^{\circ} \cdot \mathrm{ha}^{-1}\right)$ compared to pure acacia $\left(16.7 \mathrm{t} \cdot \mathrm{ha}^{-1}\right)$ and eucalypt stands $\left(15.9 \mathrm{t}^{\mathrm{h}} \mathrm{ha}^{-1}\right)$ at the end of the first 7-year rotation in the Congo (Koutika et al. 2014). This may be attributed to both the lower turnover of old $\mathrm{C}$ and a higher accretion of new $C$ (Resh et al. 2002). Another beneficial impact of $A$. mangium is its ability to contribute to climate-change mitigation goals, since emissions of $\mathrm{N}_{2} \mathrm{O}$, one of the main greenhouse gases, may be reduced by the application of its bark tannins in water-saturated soil (Matsubara and Ohta 2015).

\section{Stimulating microbial activity and $P$ availability}

Accrual in nutrients as soil $\mathrm{N}, \mathrm{P}$ and $\mathrm{C}$ in $A$. mangium monocultures or in A. mangium mixed with non-Nfixing species is due to more effective and higher nutrient cycling and availability (Santos et al. 2017a) and greater stimulation of microbial activity and dynamics in the litter (Bini et al. 2012; Pereira et al. 2018, Table 2). Distinct microbial communities have been reported in mixed $A$. mangium/E. urograndis plantations, which specific role for each species e.g., inducing an increase in nitrate amounts in the pure A. mangium stands (Rachid et al. 2013). Microbiological and chemical changes occurring in soil due to leaf litter accumulation in the intercropped plantations of eucalypt and $A$. mangium stimulate and favour plant growth (Bini et al. 2013). Litter decomposition depended on $C$ quality i.e., water soluble compounds and lignin content, but also on the activity of decomposers, which may be limited by energy starvation and by $\mathrm{P}$ deficiency, common in most tropical planted forests (Bachega et al. 2016). This common P deficiency may be partly alleviated by introducing tree NFS and non-fixing species in nutrient poor ecosystems such as savannas or grasslands (Sitters et al. 2013; Koutika and Mareschal 2017). Planting acacias and eucalypts in nutrient-poor savanna soils in the coastal Congolese plains, induced an increase in soil available $\mathrm{P}$ in the coarse particulate organic matter $(4000-250 \mu \mathrm{m})$ relative to savannas (Koutika and Mareschal 2017). 


\section{Sustaining forest productivity}

A. mangium has a positive impact on tree growth and forest productivity (Epron et al. 2013; Forrester et al. 2013; Nambiar and Harwood, 2014; Santos et al. 2017a). At the end of the first 7-year rotation of $A$. mangium and Eucalyptus urophylla $\times$ grandis plantations established in the Congolese coastal plains, eucalypt growth had benefitted from the $\mathrm{N}_{2}$ fixed by $A$. mangium, as shown by the higher wood biomass in the mixed-species than in pure eucalypt stands (Epron et al. 2013). Using ${ }^{15} \mathrm{~N}$ pulse-labelling, Paula et al. (2015) demonstrated the below-ground transfer of $\mathrm{N}$ from A. mangium to Eucalyptus grandis trees in the field in the first few days after labelling in a Brazilian planted forest, revealing the facilitation process which may ensure a significant amount of required $\mathrm{N}$ to neighbour trees. A. mangium increased the capacity of forest plantations to exploit soil deep layers when introduced alone or in mixtures with non-fixing species trees (Germon et al. 2018). Since $A$. mangium is not only renowned for its commercial uses for wood (pulp and solid) and energy, but also for its capacity to establish easily and grow rapidly in marginal land, it has been adopted and is widely preferred over other acacia species and other NFS for enhancing afforestation strategies and for improving the social welfare of smallholders in various forest transition stages in Indonesia (Permadi et al., 2017).

\section{Limitations of $A$. mangium: From benefits to threats}

The multipurpose tree A. mangium has shown many benefits outside its native range as described above. $A$. mangium may, however, have limitations for improving soil fertility and forest productivity, sequestering $\mathrm{C}$, and driving land restoration. Monospecific plantations of four native species (Dipteryx odorata, Jacaranda copaia, Parkia decussata, and Swietenia macrophylla) and the exotic A. mangium established to restore pasture areas, have shown a decline in silvicultural performance e.g., biometric data, crown projection area, total height, commercial cylinder volume etc. of A. mangium compared to other species (Machado et al. 2018). These authors did not recommend $A$. mangium for restoration because of its limited performance in relation to most of the variables that were assessed. Similarly, Parrotta and Knowles (1999) reported poor performance of fastgrowing species (i.e. eucalypt and acacia species) in facilitating the rehabilitation of mined areas in Brazil. $A$. mangium does not benefit the successional processes in Amazonian forest, compared to other restoration criteria. Although tree basal-area development of mixed commercial species was superior to all other species, they had low species richness (Parrotta and Knowles, 1999). Similarly, A. mangium did not sequester $C$ in an experimental plantation at Itatinga in Sao Paulo State,
Brazil; soil C stocks were $44 \%$ lower in the forest floor of A. mangium stands than in eucalypt stands (Voigtlaender et al. 2012).

Large plantations of fast-growing exotic species on the Congolese coastal plains may exclude colonial breeding bird species such as rosy bee-eater Merops malimbicus and Congo River martin Pseudochelidon eurystomina which rely on large open grassy plains on the coast for their breeding colonies (Hugo Rainey, Wildlife Conservation Society, pers. comm.). Such findings reinforce the concerns that have been expressed regarding the widespread planting of Australian acacias outside their native range (Richardson and Rejmánek 2011; Wilson et al. 2011; Aguiar et al. 2014; Ismael and Metali 2014).

In the absence of empirical evidence of significant long-term benefits to native biodiversity levels following the introduction of $A$. mangium, recommendations regarding its use for the purpose of 'rehabilitation' in areas where the conservation of biodiversity is the primary objective should be informed by the 'Precautionary Principle' as outlined in the Rio Declaration in 1992 (Raffensberger and Tickner 1999). Principle 15 of this Declaration states that in order to protect the environment, the precautionary approach shall be widely applied by States according to their capabilities. Where there are threats of serious or irreversible damage, lack of full scientific certainty shall be not used as a reason for postponing cost-effective measures to prevent environmental degradation'. In practice, the 'Postcautionary Principle' which is states as 'Where there are threats of serious or irreversible damage, the lack of full scientific certainty shall be used as a reason for not implementing cost-effective measures until after the environmental degradation has actually occurred' (Paull 2007), is often applied in ecological impact assessments.

\section{Threats to ecosystems and the environment from introducing $A$. mangium \\ Negative impacts on biodiversity}

Despite the many reported benefits of A. mangium in agricultural, agroforestry and forestry systems, there is increasing evidence that because of its invasive properties, this species can exert profound negative impacts on soil, biodiversity, and human wellbeing. Commercial forestry plantations are mostly established in large open areas which are highly susceptible to invasions of alien trees (Richardson and Rejmánek 2011; Attias et al. 2013; Aguiar et al. 2014; Rundel et al. 2014). Osunkoya et al. (2005) argued that Australian acacias can easily invade disturbed and degraded forests, especially those that experience drought and fire. ${ }^{\delta 15} \mathrm{~N}$ isoscapes, a useful framework for evaluating the impacts of an invasive $\mathrm{N}_{2}$-fixing species on the surrounding plants, has provided the means for quantifying the impact of invasive 
NFS by combining range, abundance and per-capita effects (Rascher et al. 2012). Aguiar et al. (2014) documented that $A$. mangium may rapidly threaten the biodiversity of Amazonian savannas surrounding large-scale plantations, based on experiments conducted aro und five plantations in Roraima, Brazil. According to these authors, one of the reasons for its wide expansion in Brazil is its use in large commercial plantations in Amazonian savannas in the 1990s without a prior assessment of the risk of invasiveness. This is also the case in some Asian countries, notably Malaysia and Vietnam (Richardson and Rejmánek 2011; Richardson et al. 2015).

Invasions of $A$. mangium started only recently, and no detailed assessment has been done to determine the types of impacts that these invasions have on aspects of biodiversity and ecosystem functioning. However, Le Maitre et al. (2011) reviewed the types of impacts ascribed to other invasive Australian acacias in many parts of the world. They found that acacias have a wide range of impacts on ecosystems that increase with time and disturbance, and frequently transform ecosystem functioning, thereby altering and reducing the delivery of ecosystem services. The accumulation of massive stores of long-lived acacia seeds in the soil ensures persistence of the invader even with frequent and severe disturbances. This is the fundamental mediator of thresholds that facilitate major biotic and abiotic impacts (Gaertner et al. 2014). Widespread invasions of Australian acacias in many parts of the world have led to increasing conflicts of interest regarding the benefits and negative impacts of the species (Kull and Rangan 2008; Richardson and Rejmánek 2011; Wilson et al. 2011; Tassin et al. 2012; Ismael and Metali 2014; Aguiar et al. 2014; Kull et al. 2018; Souza et al. 2018).

\section{Threats to human wellbeing}

Research on the negative impacts of $A$. mangium invasions on human wellbeing began only very recently. In savanna areas surrounding indigenous lands in Roraima State, Brazil where 30,000 ha of A. mangium were planted for commercial purposes, Souza et al. (2018) undertook interviews in three communities. They found that $A$. mangium was perceived to have negative effects on the natural environment and on human livelihoods in the subsistence of their communities.

\section{Negative impacts on soils}

Changes in the functional diversity of soil microorganisms (mycorrhizal fungi and rhizobia) inhibited the growth of the native tree species Faidherbia albida and Quercus suber while restoring degraded lands in Senegal and Algeria with two Australian acacias, A. holosericea and A. mearnsii (Duponnois et al. 2013). Another Australian acacia, A. dealbata, established positive plant-soil feedbacks which are important mechanisms for its further invasion (Gaertner et al. 2014), and showed a strong competitive ability relative to the native trees (Rodriguez-Echeverria et al. 2013). A. mangium may have negative impacts on the concentrations of soil nutrients and neighbouring plants (Liu et al. 2017; Meira-Neto et al. 2018). In its early invasion stage, A. mangium is able to alter both soil and leaf nitrogen, increase shade and enable a wider range of light variation, which is facilitated by the nitrogen taken up and transferred to neighbouring plants (Meira-Neto et al. 2018). In plantations of acacia and eucalypt in the Congolese coastal plains, soil resin $\mathrm{P}$ availability decreased in the top soil in the mixed-species (50\% acacia and 50\% eucalypt) compared to pure eucalypt stands at the end of the first 7-year rotation (Koutika et al. 2014). This change in P was noticed further by a decrease in soil readily available inorganic $\mathrm{P}$ (resin and $\mathrm{Pi}-\mathrm{HCO}_{3}$ ) in acacia relative to pure eucalypt stands at year 2 of the second rotation compared to the end of the first rotation (Koutika et al. 2016). In the eucalypt and acacia plantations located in Rio de Janeiro state, Brazil, Santos et al. (2017b) demonstrated that eucalypt deposited greater quantities of $\mathrm{P}$ via litter, but little $\mathrm{N}$, while acacia did the opposite. In subtropical China, Liu et al. (2017) showed that NFS ( $A$. mangium and Ormosia pinnata) had higher P uptake capacity than non-NFS under ambient $\mathrm{N}$ deposition. These findings may reveal a possible risk of shifting from $\mathrm{N}$-limitation to soil $\mathrm{P}$ limitation in the longer term involving a decrease in forest productivity. This may occur in pure acacia stands in the Congolese coastal plains (Koutika et al. 2016), or when $\mathrm{N}$ deposition continue since high amounts of $\mathrm{N}$ may decrease soil microbial activity of NFS in subtropical China (Liu et al. 2017). It has to be noted that $A$. mangium is mostly introduced in the tropical climates and nutrient-poor soils, where $\mathrm{N}$ is the most limited nutrient, and also where $\mathrm{P}$ availability is reduced by strong adsorption due to the large amounts of $\mathrm{Al}$ and $\mathrm{Fe}$ oxide surfaces in most of tropical soils (Sanchez and Uehara 1980).

\section{Negative effects on water availability}

In some dry or water-limited areas, introducing alien NFS such as Australian acacias may change seasonal water use patterns (Rascher et al. 2011; Siddiq and Cao 2016). Siddiq and Cao (2016) evaluated the seasonal water use and stand-level transpiration of eight, evergreen, dipterocarps in tropical Southwest China during the wet and dry seasons with six species in monoculture and two species in mixture. The introduced fast-growing species, such as eucalypts and $A$. mangium, consumed much more water than dipterocarp trees and forests, which are more suitable as plantation timber crops for the region (Siddiq and Cao 2016). 


\section{Can potential negative impacts of $\boldsymbol{A}$. mangium due to invasiveness be mitigated?}

Is it possible to plan for the sustainable use of $A$. mangium i.e., reaping benefits yet limiting negative impacts? The threats of $A$. mangium on ecosystems and biodiversity outside its native environment are obvious (Wilson et al. 2011; Low 2012; Attias et al. 2013; Sampaio and Schmidt 2013; Aguiar et al. 2014; Richardson et al. 2015; Nambiar et al. 2018). From experience in parts of the world with a long history of plantings of Australian acacias, three main issues warrant careful attention when considering issues relating to invasiveness and management of invasive acacias: 1) the role of residence time and invasion debt; 2) massive seed production; and 3) biological control (van Wilgen et al. 2011; Richardson et al. 2015).

\section{Residence time and invasion debt}

All species of Australian acacias that have been widely planted outside their native range over decades have become invasive and have caused negative impacts. Invasions and associated impacts typically manifest only several decades after large-scale plantings (Richardson et al. 2011; Richardson et al. 2015). Given the relatively recent expansion of $A$. mangium plantings (Table 1 ), the lack of major problems with invasiveness until now in some areas has probably led to the assumption that the species poses limited problems with invasiveness. As far as we know, little or no attention was given to issues pertaining to invasiveness when planning major plantings in any of the areas listed in Table 1. Several lifehistory traits of $A$. mangium are strongly associated with invasiveness in woody plants: these include rapid growth, and the capacity to produce very large numbers of hard-coated, heat-tolerant and long-lived seeds that are adapted for long-distance dispersal by birds (Awang and Taylor; 1993; Franco et al. 1994; Gibson et al. 2011). Suhaili et al. (2015) argued that invasions of A. mangium into tropical heath forests of Borneo may be controlled by a proper management of plantations and monitoring of soil seed banks, but we could find no evidence that this has been attempted or is likely to be practical.

The massive seed production of $A$. mangium in the absence of native enemies is the fundamental driver of invasions. Research on plantings and invasions of other Australian acacias has shown that the type and configuration of plantings is important for determining the trajectory of invasions (Donaldson et al. 2014). Biological invasions proceed more quickly and are more likely to result in landscape-scale invasions when plantings take the form of large commercial plantations which provide a massive propagule source. In most cases, such plantations are situated in open vegetation (grassland or scrublands) and/or in areas adjoining natural vegetation which ensures large areas of habitat that are open to invasion. Plantings for ornamentation or for other purposes generally provide smaller propagule sources and have less chance of seeding massive invasions (Donaldson et al. 2014). A. mangium has been mainly introduced for pulpwood, soil fertility improvement and land restoration in Asia, Africa and South America (Franco and de Faria, 1997; Epron et al. 2013; Permadi et al., 2017). This may partly explain the rapid and widespread spread.

\section{Biological control}

The use of seed-attacking insects and fungi for biological control is a key component of integrated control strategies against Australian acacias, especially in South Africa (Richardson and Kluge 2008; Impson et al. 2009). These efforts have, over several decades, significantly reduced seed production of several invasive acacias, have reduced the density of some invasive populations, and seem to be reducing the spread rates, thereby contributing to overall control aims. Many other types of control are also being used to deal with current and potential future problems with invasive Australian acacias. These include: risk assessment (to help identify highly invasive species that are not yet in the country); eradication (to totally remove populations of those species that still occur over small areas and at low densities, e.g. Kaplan et al. 2012, 2014); containment using mechanical and chemical control; exploitative harvesting of invasive populations (e.g. for fire wood); research to develop of sterile cultivars of commercially important species (Wilson et al. 2011; Harbard et al. 2012;); spatial prioritization of control operations (Roura-Pascual et al. 2009); education and raising awareness; the use of legislation to assign responsibility of control and legislation to prohibit cultivation (Aguiar et al. 2014), prohibition of trade of some species in certain areas (van Wilgen et al. 2011). All of these components of management could reduce problems associated with invasiveness of $A$. mangium and should be considered when assessing risks associated with plantings and in compiling management plans for reducing problems that already exist.

\section{Conclusions}

A. mangium has obvious benefits for improving soil fertility in agriculture, agroforestry and forestry in areas with nutrient-poor soils, and for restoring degraded lands and ecosystems. However, the species has the potential to cause major negative impacts to biodiversity and ecosystem functioning when it becomes invasive. The ecology of the species in most parts of its introduced range remains poorly understood. Experience in those parts of the world with long histories of planting A. mangium and other Australian acacias provide useful previews of future problems, and such insights must be 


\section{considered when evaluating costs and benefits of new plantings.}

\section{Abbreviations}

NFS: Nitrogen fixing species; POM: Particulate organic matter; SOM: Soil organic matter

\section{Acknowledgements}

We thank Dr. Kai Sonder (CIMMYT, Texcoco, Mexico), Dr. Claudia Maia (EMBRAPA Floresta, Colombo, Brazil) and Prof. Daniel Epron (Université de Lorraine, France) for contributing material for this review, and Prof. Dan Binkley (Colorado State University, USA), Dr. Hugo Rainey (Wildlife Conservation Society, USA) and Dr. Ilias Travlos (Agricultural University of Athens, Greece) for their inputs to an early version. Dr. Sarah Whitfeld (Curator, Australian Tree Seed Centre (ATSC), National Research Collections Australia, CSIRO) kindly provided data on dispatches of A. mangium seed from the ATSC.

\section{Funding}

DMR acknowledges funding from the DST-NRF Centre of Excellence for Invasion Biology and the National Research Foundation, South Africa (grant 85417).

\section{Availability of data and materials}

Not applicable

\section{Authors' contributions}

LSK planned the project, undertook most of the literature review, and wrote the first draft. DMR contributed additional literature and contributed substantially to interpretation and writing. Both authors read and approved the final manuscript

\section{Authors' information}

LSK is a soil scientist at the Forestry Research Centre (CRDPI), Pointe-Noire, Congo. She works on soil organic matter (both C and N) and phosphorus dynamics in the mixed-species of eucalypts and Acacia mangium plantations established in the Congolese coastal plains.

DMR is Director of the DST-NRF Centre of Excellence for Invasion Biology (http://academic.sun.ac.za/cib/) and Distinguished Professor of Ecology at Stellenbosch University, South Africa. His research focusses on the ecology and management of invasive plants, especially trees and he has worked on many of the 23 species of Australian acacias known to be invasive in different parts of the world.

\section{Ethics approval and consent to participate}

Not applicable

\section{Consent for publication}

Not applicable

\section{Competing interests}

The authors declare that they have no competing interests.

\section{Author details}

'CRDPI, Centre de Recherche sur la Durabilité et la Productivité des Plantations Industrielles, BP 1291 Pointe-Noire, Republic of the Congo. ${ }^{2}$ Centre for Invasion Biology, Department of Botany \& Zoology, Stellenbosch University, Matieland 7602, South Africa.

Received: 27 August 2018 Accepted: 4 January 2019

Published online: 29 January 2019

\section{References}

Aguiar A, Barbosa Rl, Barbosa JBF, Mourao MJ (2014) Invasion of Acacia mangium in Amazonian savannas following planting of forestry. Plant Ecol Divers (1-2): 359-369. https://doi.org/10.1080/17550874.2013.771714

Arisman $\mathrm{H}$, Hardiyanto EB (2006) Acacia mangium - a historical perspective on its cultivation. In: Potter K, Rimbawanto A, Beadle C (eds) Heart rot and root rot in tropical Acacia plantations. Proceedings of a workshop held in Yogyakarta, Indonesia, February 7-9, 2006, Canberra: Australia Centre for International Research, ACIAR proceedings no. 124, pp 11-15
Attias N, Ferreira Siqueira M, de Godoy BH (2013) Acácias Australianas no Brasil: Histórico, Formas de Uso e Potencial de Invasão. Biodiversidade Bras 3(2):74-96

Awang K, Taylor D (1993) Acacia mangium, growing and utilization. In: FAO and Winrock international, MPTS monograph series no. 3, Bangkok, Thailand

Bachega LR, Bouillet J-P, de Cássia Piccolo M, Saint-André L, Bouvet J-M, Nouvellon Y, de Moraes Gonçalves JL, Robin A, Laclau J-P (2016) Decomposition of Eucalyptus grandis and Acacia mangium leaves and fine roots in tropical conditions did not meet the home field advantage hypothesis. For Ecol Manag 359:33-43

Bernhard-Reversat F (1993) Dynamics of litter and organic matter at the soil-litter interface of fast-growing tree plantations on sandy ferrallitic soils (Congo). Acta Ecol 14(2):179-195

Bini D, dos Santos CA, Bouillet J-P, de Morais Goncalves JL, Cardosoa EJBN (2013) Eucalyptus grandis and Acacia mangium in monoculture and intercropped plantations: evolution of soil and litter microbial and chemical attributes during early stages of plant development. Appl Soil Ecol 63:57-66

Bini D, Figueiredo AF, da Silva MCP, de Figueiredo Vasconcellos RL, Cardoso EJBN (2012) Microbial biomass and activity in litter during the initial development of pure and mixed plantations of Eucalyptus grandis and Acacia mangium. Rev Bras Cienc Solo 37:76-85

Binkley D (1992) Mixtures of $\mathrm{N}_{2}$-fixing and non- $\mathrm{N}_{2}$-fixing tree species. In: Cannell MGR, Malcom DC, Robertson PA (eds) The ecology of mixed species stands of trees. Blackwell Scientific Publications, Oxford

Bouillet J-P, Laclau JP, Gonçalves JLM, Voigtlaender M, Gava JL, Leite FP, Hakamada R, Mareschal L, Mabiala A, Tardy F, Levillain J, Deleporte P, Epron D, Nouvellon Y (2013) Eucalyptus and Acacia tree growth over entire rotation in single- and mixed-species plantations across five sites in Brazil and Congo. For Ecol Manag 301:89-101

Castro-Díez P, Godoy O, Saldaña A, Richardson DM (2011) Predicting invasiveness of Australian Acacia species on the basis of their native climatic affinities, lifehistory traits and human use. Divers Distrib 17:934-945

Chaer GM, Resende AS, Campello EFC, de Faria SM, Boddey RM (2011) Nitrogenfixing legume tree species for the reclamation of severely degraded lands in Brazil. Tree Physiol 31:139-149. https://doi.org/10.1093/treephys/tpq116

Chazdon RL (2008) Beyond deforestation: restoring forests and ecosystem services on degraded lands. Science 320:1458-1460

Chen D, Zhang C, Wu J, Zhou L, Lin Y, Fu S (2011) Subtropical plantations are large carbon sinks: evidence from two monoculture plantations in South China. Agric For Meteorol 151:1214-1225

Coetzee MPA, Wingfield BD, Golani GD, Tjahjono B, Gafur A, Wingfield MJ (2011) A single dominant Ganoderma species is responsible for root rot of Acacia mangium and Eucalyptus in Sumatra. South Forests 73(3-4): $175-180$

Cole TG, Yost RS, Kablan R, Olsen T (1996) Growth potential of twelve Acacia species on acid soils in Hawaii. For Ecol Manag 80:175-186

Dickie IA, Bennett BM, Burrows LE, Nuñez MA, Peltzer DA, Porté A, Richardson DM, Rejmánek M, Rundel PW, van Wilgen BW (2014) Conflicting values: ecosystem services and invasive tree management. Biol Invasions 16:705719. https://doi.org/10.1007/s10530-013-0609-6

Donaldson JE, Hui C, Richardson DM, Robertson MP, Webber BL, Wilson JRU (2014) Invasion trajectory of alien trees: the role of introduction pathway and planning history. Glob Change Biol. https://doi.org/10.1111/gcb.12486

Dubliez E, Freycon V, Marien JM, Peltier R, Harmand JM (2018) Long term impact of Acacia auriculiformis woodlots growing in rotation with cassava and maize on the carbon and nutrient contents of savannah sandy soils in the humid tropics (Democratic Republic of Congo). Agrofor Syst. https://doi.org/10. 1007/s10457-018-0222-x

Duponnois R, Baudoin E, Sanguin H, Thioulouse J, Le Roux C, Tournier E, Galiana A, Prin Y, Dreyfus B (2013) L'introduction d'acacias australiens pour réhabiliter des écosystèmes dégradés est-elle dépourvue de risques environnementaux ? Bois For Trop 318(4):59-65

Epron D, Nouvellon Y, Mareschal L, Moreira RM, Koutika L-S, Geneste B, DelgadoRojas JS, Laclau J-P, Sola G, Gonçalves JLM, Bouillet J-P (2013) Partitioning of net primary production in Eucalyptus and Acacia stands and in mixed-species plantations: two case-studies in contrasting tropical environments. For Ecol Manag 301:102-111

Eyles A, Beadle C, Barry K, Francis A, Glen M, Mohammed C (2008) Management of fungal root-rot pathogens in tropical Acacia mangium plantations. Forest Pathol 38:332-355 
Forrester DI, Pares A, O'Hara C, Khanna PK, Bauhus J (2013) Soil organic carbon is increased in mixed-species plantations of eucalyptus and nitrogen-fixing Acacia. Ecosystems 16:123-132

Franco AA, Campello AFC, Dias LE, de Farla SM (1994) Revegetation of acidic residues from bauxite mining using nodulated and mycorrhizal legume trees. In: Proceedings Nitrogen-Fixing Tree, Turrialba, pp 313-320

Franco AA, de Faria SM (1997) The contribution of $\mathrm{N}_{2}$-fixing tree legumes to land reclamation and sustainability in the tropics. Soil Biol Biochem 29:897-903

Frey GE, Cubbage FW, Ha TT, Davis RR, Carle JB, Thon VX, Dzung NV (2018) Financial analysis and comparison of smallholder forest and state forest enterprise plantations in Central Vietnam. Int For Rev 20:181-198. https://doi. org/10.1505/146554818823767582

Fuentes-Ramírez A, Pauchard A, Cavieres LA, García RA (2011) Survival and growth of Acacia dealbata vs. native trees across an invasion front in southCentral Chile. For Ecol Manag 261:1003-1009

Gaertner M, Biggs R, Te Beest M, Hui C, Molofsky J, Richardson DM (2014) Invasive plants as drivers of regime shifts: identifying high priority invaders that alter feedback relationships. Divers Distrib 20:733-744. https://doi.org/10. 1111/ddi.12182

Germon A, Guerrini IA, Bordron B, Bouillet J-P, Nouvellon Y, Gonçalves JLde M, Jourdan C, Paula RR, Laclau J-P (2018) Consequences of mixing Acacia mangium and Eucalyptus grandis trees on soil exploration by fine-roots down to a depth of $17 \mathrm{~m}$. Plant Soil 424:203-220. https://doi.org/10.1007/s11104017-3428-1

Gibson MR, Richardson DM, Marchante EM, Hélia R, James GS, Graham NB, Margaret F-R, Andrés G, Nicholas H, Carla J, Steven DR, Johannes JLM, Joseph TM, Daniel JP, Anton P, Matthew NW, Elizabeth MW, John RU (2011) Reproductive ecology of Australian acacias: important mediator of invasive success? Divers Distrib 17:911-933

Hagos MG, Smit GN (2005) Soil enrichment by Acacia mellifera ssp. detinens on nutrient poor sandy soil in a semi-arid southern African savanna. J Arid Environ 61:47-59

Hai PH, Duong LA, Toan NQ, Ha TT (2015) Genetic variation in growth, stem straightness, pilodyn and dynamic modulus of elasticity in secondgeneration progeny tests of Acacia mangium at three sites in Vietnam. New Forest 46:577-591. https://doi.org/10.1007/s11056-015-9484-6

Harbard JL, Griffin AR, Foster C, Brooker LD, Kha LD, Koutoulis A (2012) Production of colchine-induced autotetraploids as a basis for sterility breeding in Acacia mangium Willd. Forestry 85(3):427-436. https://doi.org/10. 1093/forestry/cps041

Huang X, Liu S, Wang H, Hu Z, Li Z, You Y (2014) Changes in soil microbial biomass carbon and community composition through mixing nitrogen-fixing species with Eucalyptus urophilla in subtropical China. Soil Biol Biochem 73: $42-48$

Impson FAC, Hoffmann J, Kleinjan C (2009) Australian Acacia species (Mimosaceae) in South Africa. In: Muniappan R, Reddy GVP, Raman A (eds) Biological control of tropical weeds using arthropods. Cambridge University Press, Cambridge and New York, pp 38-62

Inagaki M, Kamo K, Miyamoto K, Titin J, Jamalung L, Lapongan J, Miura S (2011) Nitrogen and phosphorus retranslocation and N:P ratios of litterfall in three tropical plantations: luxurious $\mathrm{N}$ and efficient $\mathrm{P}$ use by Acacia mangium. Plant Soil 341:295-307

Ismael NAN, Metali F (2014) Allelopathic effects of invasive Acacia mangium on germination and growth of local paddy varieties. J Agron 13(4):158-168. https://doi.org/10.3923/ja.2014.158.168

Kaplan H, van Niekerk A, Le Roux JJ, Richardson DM, Wilson JRU (2014) Incorporating risk mapping at multiple spatial scales into eradication management plans. Biol Invasions 16:691-703. https://doi.org/10.1007/ s10530-013-0611-z

Kaplan H, Van Zyl HWF, Le Roux JJ, Richardson DM, Wilson JRU (2012) Distribution and management of Acacia implexa in South Africa: is eradication an option? S Afr J Bot 83:23-35. https://doi.org/10.1016/j.sajb. 2012.07.016

Kasongo RK, Van Ranst E, Verdoodt A, Kanyankagote P, Baert G (2009) Impact of Acacia auriculiformis on the chemical fertility of sandy soils on the Batéké plateau, D.R. Congo. Soil Use Manage 25:21-27

Kaye JP, Resh SC, Kaye MW, Chimner RA (2000) Nutrient and carbon dynamics in a replacement series of eucalyptus and Albizia trees. Ecology 81:3267-3273

Khanna P (1998) Nutrient cycling under mixed-species tree systems in Southeast Asia. Agrofor Syst 38:99-120
Koutika L-S, Epron D, Bouillet J-P, Mareschal L (2014) Changes in N and C concentrations, soil acidity and $\mathrm{P}$ availability in tropical mixed acacia and eucalypt plantations on a nutrient-poor sandy soil. Plant Soil 379:205-216

Koutika L-S, Mareschal L (2017) Acacia and eucalypt change P, N and C concentrations in POM of arenosols in the Congolese coastal plains. Geoderma Reg 11:37-43. https://doi.org/10.1016/j.geodrs.2017.07.009

Koutika L-S, Mareschal L, Epron D (2016) Soil P availability under eucalypt and acacia on Ferralic Arenosols, republic of the Congo. Geoderma Reg 7:153-158

Koutika LS, Mareschal L, Rudowski S (2018) Fate of Acacia mangium in eucalypt mixed-species plantation during drought conditions in the Congolese coastal plains. Bosque 39(1):131-136. https://doi.org/10.4067/S071792002018000100012

Koutika L-S, Tchichelle SV, Mareschal L, Epron D (2017) Nitrogen dynamics in a nutrient-poor soil under mixed-species plantations of eucalypts and acacias. Soil Biol Biochem 108:84-90

Kull CA, Kueffer C, Richardson DM, Vaz AS, Vicente J, Honrado JP (2018) Using the 'regime shift' concept in addressing social-ecological change. Geogr Res 56: 26-41. https://doi.org/10.1111/1745-5871.12267

Kull CA, Rangan H (2008) Acacia exchanges: wattles, thorn trees, and the study of plant movements. Geoforum 39:1258-1272

Kull CA, Shackleton CM, Cunningham PJ, Ducatillon C, Dufour-Dror JM, Esler KJ, Friday JB, Gouveia AC, Griffin AR, Marchante E, Midgley SJ, Pauchard A, Rangan H, Richardson DM, Rinaudo T, Tassin J, Urgenson LS, von Maltitz GP, Zenni RD, Zylstra MJ (2011) Adoption, use and perception of Australian acacias around the world. Divers Distrib 17:822-836

Kull CA, Tassin J, Rangan H (2007) Multifunctional, scrubby, and invasive forests? Wattles in the highlands of Madagascar. Mt Res Dev 27:224-231

Le Maitre DC, Gaertner M, Marchante E, Ens EJ, Holmes PM, Pauchard A, O'Farrell PJ, Rogers AM, Blanchard R, Blignaut J, Richardson DM (2011) Impacts of invasive Australian acacias: implications for management and restoration. Divers Distrib 17:1015-1029

Lee KL, Ong KH, King PJH, Chubo JK, Su DSA (2015) Stand productivity, carbon content, and soil nutrients in different stand ages of Acacia mangium in Sarawak, Malaysia. Turk J Agric For 39:154-161. https://doi.org/10.3906/tar1404-20

Liu J, Li Y, Xu Y, Liu S, Huang W, Fang X, Yin G (2017) Phosphorus uptake in four tree species under nitrogen addition in subtropical China. Environ Sci Pollut R 24:20005-20014. https://doi.org/10.1007/s11356-017-9633-x

Low T (2012) Australian acacias: weeds or useful trees? Biol Invasions 14:22172227. https://doi.org/10.1007/s10530-012-0243-8

Ludwig F, de Kroon H, Berendse F, Prins HT (2004) The influence of savanna trees on nutrient, water and light availability and the understorey vegetation. Plant Ecol 170:93-105

Machado MR, Camara R, Sampaio PTB, Ferraz JBS, Pereira MG (2018) Silvicultural performance of five forest species in the central Brazilian Amazon. Acta Amazon 48:10-17

Machado MR, Camara R, Sampaio PTB, Pereira MG, Silva Ferraz JB (2017) Land cover changes affect soil chemical attributes in the Brazilian Amazon. Acta Sci-Agron 39(3):385-391. https://doi.org/10.4025/actasciagron.v39i3.32689

Matsubara K, Ohta S (2015) The effects of tannins derived from Acacia mangium bark on $\mathrm{N}_{2} \mathrm{O}$ emissions from water saturated acacia plantation soil. Tropics 24(2):65-74. https://doi.org/10.3759/tropics.24.65

Meira-Neto JAA, da Silva MCNA, Tolentino GS, Gastauer M, Buttschardt T, UIm F, Maguas C (2018) Early Acacia invasion in a sandy ecosystem enables shading mediated by soil, leaf nitrogen and facilitation. Biol Invasions 20:1567-1575. https://doi.org/10.1007/s10530-017-1647-2

Midgley SJ, Turnbull JW (2003) Domestication and use of Australian acacias: case studies of five important species. Aust Syst Bot 16:89-102

Nambiar EKS, Harwood CE (2014) Productivity of acacia and eucalypt plantations in Southeast Asia. 1. Bio-physical determinants of production: opportunities and challenges. Inter For Rev 16(2):225-248

Nambiar EKS, Harwood CE, Kien ND (2014) Acacia plantations in Vietnam: research and knowledge application to secure a sustainable future. South For. https://doi.org/10.2989/20702620.2014.999301

Nambiar EKS, Harwood CE, Mendham DS (2018) Paths to sustainable wood supply to the pulp and paper industry in Indonesia after diseases have forced a change of species from acacia to eucalypts. Aust For. https://doi. org/10.1080/00049158.2018.1482798 Accessed 20 Sep 2018

National Research Council (1983) Mangium and other fast-growing Acacias for the humid tropics. National Academic Press, Washington D.C., p 63 
Oelofse M, Birch-Thomsen T, Magid J, de Neergaard A, van Deventer R, Bruun S, Hill T (2016) The impact of black wattle encroachment of indigenous grasslands on soil carbon, eastern cape, South Africa. Biol Invasions 18:445456. https://doi.org/10.1007/s10530-015-1017-x

Osunkoya OO, Othman FE, Kahar RS (2005) Growth and competition between seedlings of an invasive plantation tree, Acacia mangium, and those of a native Borneo heath-forest species, Melastoma beccarianum. Ecol Res 20:205214. https://doi.org/10.1007/s11284-004-0027-4

Otsamo A, Adjers G, Hadi TS, Kuusipalo J, Vuokko R (1997) Evaluation of reforestation potential of 83 tree species planted on Imperata cylindrica dominated grassland, a case study from South Kalimantan, Indonesia. New For 14:127-143

Parrotta JA (1999) Productivity, nutrient cycling and succession in single-and mixed-species plantations of Casuarina equisetifolia, Eucalyptus robusta and Leucaena leucocephala in Puerto Rico. For Ecol Manag 124:47-77

Parrotta JA, Knowles OH (1999) Restoration of tropical moist forests on bauxitemined lands in the Brazilian Amazon. Restor Ecol 7(2):103-116

Paula RR, Bouillet J-P, Trivelin PCO, Zeller B, de Moraes Gonçalves JL, Nouvellon Y, Bouvet J-M, Plassard C, Laclau J-P (2015) Evidence of short-term belowground transfer of nitrogen from Acacia mangium to Eucalyptus grandis trees in a tropical planted forest. Soil Biol Biochem 91:99-108

Paull J (2007) Certified Organic Forests \& Timber: the Hippocratic opportunity. In: Proceedings of the ANZSEE conference 2007, pp 1-14

Pereira AP, de Andrade PA, Bini D, Durrer A, Robin A, Bouillet J-P, Andreote FD, EJBN C (2017) Shifts in the bacterial community composition along deep soi profiles in monospecific and mixed stands of Eucalyptus grandis and Acacia mangium. PLoS One 12(7):e0180371

Pereira APA, Zagatto MRG, Brandani CB, Mescolotti DL, Cotta SR, Gonçalves JLM Cardoso EJBN (2018) Acacia changes microbial indicators and increases $C$ and $\mathrm{N}$ in soil organic fractions in intercropped eucalyptus plantations. Front Microbiol 9:655. https://doi.org/10.3389/fmicb.2018.00655

Permadi DB, Burtona M, Pandita R, Walker I, Race D (2017) Which smallholders are willing to adopt Acacia mangium under long-term contracts? Evidence from a choice experiment study in Indonesia. Land Use Policy 65:211-223

Rachid CTCC, Balieiro FC, Peixoto RS, Pinheiro YAS, Piccolo MC, Chaer GM, Rosado AS (2013) Mixed plantations can promote microbial integration and soil nitrate increases with changes in the $\mathrm{N}$ cycling genes. Soil Biol Biochem 66:146-153

Raffensberger C, Tickner J (1999) Protecting public health and the environment: implementing the precautionary principle. Island Press, Washington D.C

Rascher KG, Große-Stoltenberg A, Maguas C, Werner C (2011) Understory invasion by Acacia longifolia alters the water balance and carbon gain of a Mediterranean pine. Ecosystems 14:904-919. https://doi.org/10.1007/s10021011-9453-7

Rascher KG, Hellmann C, Maguas C, Werner C (2012) Community scale 15N isoscapes: tracing the spatial impact of an exotic $\mathrm{N}_{2}$-fixing invader. Ecol Lett 15:484-491. https://doi.org/10.1111/j.1461-0248.2012.01761.x

Rejmánek M, Richardson DM (2013) Trees and shrubs as invasive alien species 2013 update of the global database. Divers Distrib 19:1093-1094

Resh SC, Binkley D, Parrotta JA (2002) Greater soil carbon sequestration under nitrogen-fixing trees compared with Eucalyptus species. Ecosystems 5:217231

Richardson DM, Binggeli P, Schroth G (2004) Invasive agroforestry trees: problems and solutions. In: Agroforestry and biodiversity conservation in tropical landscapes. Island Press, Washington, D.C., pp 371-396

Richardson DM, Carruthers J, Hui C, Impson FAC, Robertson MP, Rouget M, Le Roux JJ, Wilson JRU (2011) Human-mediated introductions of Australian acacias - a global experiment in biogeography. Divers Distrib 17:771-787

Richardson DM, Kluge RL (2008) Seed banks of invasive Australian Acacia species in South Africa: role in invasiveness and options for management. Perspect Plant Ecol Evol Syst 10:161-177

Richardson DM, Le Roux JJ, Wilson JRU (2015) Australian acacias as invasive species: lessons to be learnt from regions with long planting histories. South Forests 77(1):31-39. https://doi.org/10.2989/20702620.2014.999305

Richardson DM, Rejmánek M (2011) Trees and shrubs as invasive alien species - a global review. Divers Distrib 17:788-809. https://doi.org/10.1111/j.1472-4642. 2011.00782.x

Rodriguez-Echeverria S, Afonso C, Correia M, Lorenzo P, Roiloa SR (2013) The effect of soil legacy on competition and invasion by Acacia dealbata link. Plant Ecol 214:1139-1146. https://doi.org/10.1007/s11258-013-0238-2
Rouget M, Robertson MP, Wilson JRU, Hui C, Essl F, Renteria JL, Richardson DM (2016) Invasion debt - quantifying future biological invasions. Divers Distrib 22:445-456

Roura-Pascual N, Richardson DM, Krug RM, Brown A, Chapman RA, Forsyth GG, Le Maitre DC, Robertson MP, Stafford L, Van Wilgen BW, Wannenburgh A, Wessels N (2009) Ecology and management of alien plant invasions in south African fynbos: accommodating key complexities in objective decision making. Biol Conserv 142:1595-1604

Rundel PW, Dickie IE, Richardson DM (2014) Tree invasions into treeless areas: mechanisms and ecosystem processes. Biol Invasions 16:663-675

Sampaio AB, Schmidt IB (2013) Espécies Exóticas Invasoras em Unidades de Conservação Federais do Brasil. Biodiversidade Brasileira 3(2):32-49

Sanchez PA, Uehara G (1980) Management considerations for acid soils with high phosphorus fixation capacity. In: Khasawneh FE, Sample EC, Kamprath EJ (eds) The role of phosphorus in agriculture. Am Soc, Madison, pp 417-514

Sang PM, Lamb D, Bonner M, Schmidt S (2013) Carbon sequestration and soil fertility of tropical tree plantations and secondary forest established on degraded land. Plant Soil 362:187-200. https://doi.org/10.1007/s11104012-1281-9

Sanginga N, Mulungoy K, Ayanaba A (1986) Inoculation of Leucaena leucocephala lam de Witt with rhizobium and its nitrogen contribution to a subsequent maize crop. Biol Agric Hortic 3:341-352

Santos FM, Balieiro FC, Fontes MA, Chaer GM (2017b) Understanding the enhanced litter decomposition of mixed-species plantations of Eucalyptus and Acacia mangium. Plant Soil. https://doi.org/10.1007/s11104-017-3491-7 Accessed 20 Sep 2018

Santos FM, Chaer GM, Diniz AR, de Carvalho Balieiro F (2017a) Nutrient cycling over five years of mixed-species plantations of eucalyptus and Acacia on a sandy tropical soil. For Ecol Manag 384:110-121. https://doi.org/10.1016/j. foreco.2016.10.041

Shackleton RT, Biggs R, Richardson DM, Larson BMH (2018) Social-ecological drivers and impacts of invasion-related regime shifts: consequences for ecosystem services and human wellbeing. Environ Sci Pol 89:300-314. https://doi.org/10.1016/j.envsci.2018.08.005 Accessed 20 Sep 2018

Shure J, Marien JN, de Wasseige C, Drigo R, Salbitano F, Dirou S, Nkoua M (2010) Contribution du bois énergie à la satisfaction des besoins énergétiques des populations d'Afrique Centrale. In: Perspectives pour une gestion durable des ressources disponibles, pp 109-122

Siddiq Z, Cao K-F (2016) Increased water use in dry season in eight dipterocarp species in a common plantation in the northern boundary of Asian tropics. Ecohydrology 9:871-881. https://doi.org/10.1002/eco.1689

Sitters J, Edwards PJ, Venterink HO (2013) Increases of soil C, N, and P pools along an Acacia tree density gradient and their effects on trees and grasses. Ecosystems 16:347-357

Souza AO, Chaves MPSR, Barbosa Rl, Clement CR (2018) Local ecological knowledge concerning the invasion of Amerindian lands in the northern Brazilian Amazon by Acacia mangium (Willd.). J Ethnobiol Ethnomed 14:-33

Suhaili ALR, Tennakoon KU, Sukri RS (2015) Soil seed bank of an exotic Acacia sp. plantation and an adjacent tropical heath forest in Brunei Darussalam. Biotropia 22:140-150. https://doi.org/10.11598/btb.2015.22.2.487

Tassin J, Rangan H, Kull CA (2012) Hybrid improved tree fallows: harnessing invasive woody legumes for agroforestry. Agrofor Syst 84:417-428. https:// doi.org/10.1007/s10457-012-9493-9

Tchichelle SV, Epron D, Mialoundama F, Koutika L-S, Harmand J-M, Bouillet JP, Mareschal $L$ (2017) Differences in nitrogen cycling and soil mineralisation between a eucalypt plantation and a mixed eucalypt and Acacia mangium plantation on a sandy tropical soil. Sth For. https://doi.org/10.2989/20702620. 2016.1221702

Van Wilgen BW, Dyer C, Hoffmann JH, Ivey P, Le Maitre DC, Moore JL, Richardson DM, Rouget M, Wannenburgh A, Wilson JRU (2011) National-scale strategic approaches for managing introduced plants: insights from Australian acacias in South Africa. Divers Distrib 17:1060-1075. https://doi.org/10.1111/j.14724642.2011.00785.x

Van Wilgen BW, Richardson DM (2014) Managing invasive alien trees: challenges and trade-offs. Biol Invasions 16:721-734. https://doi.org/10.1007/s10530-0130615-8

Voigtlaender M, Laclau J-P, Gonçalves JLM, Piccolo MC, Moreira MZ, Nouvellon Y, Ranger J, Bouillet J-P (2012) Introducing Acacia mangium trees in Eucalyptus grandis plantations: consequences for soil organic matter stocks and nitrogen mineralization. Plant Soil 352:99-111 
Wang F, Li Z, Xia H, Zou B, Li N, Liu J, Zhu W (2010) Effects of nitrogen-fixing and non-nitrogen-fixing tree species on soil properties and nitrogen transformation during forest restoration in southern China. Soil Sci Plant Nutr 56(2):297-306. https://doi.org/10.1111/j.1747-0765.2010.00454.x

Wilson JRU, Gairifo C, Gibson MR, Arianoutsou M, Bakar BB, Baret S, CelestiGrapow L, DiTomaso JM, Dufour-Dror JM, Kueffer C, Kull CA, Hoffmann JH, Impson FAC, Loope LL, Marchante E, Marchante H, Moore JL, Murphy DJ, Tassin J, Witt A, Zenni RD, Richardson DM (2011) Risk assessment, eradication, and biological control: global efforts to limit Australian acacia invasions. Divers Distrib 17:1030-1046. https://doi.org/10.1111/j.1472-4642. 2011.00815.x

Witt A (2017) Guide to the naturalized and invasive plants of Southeast Asia. CABI, Wallingford, U.K.

Yang L, Liu N, Ren H, Wanga J (2009) Facilitation by two exotic Acacia: Acacia auriculiformis and Acacia mangium as nurse plants in South China. For Ecol Manag 257:1786-1793

\section{Submit your manuscript to a SpringerOpen ${ }^{\circ}$ journal and benefit from:}

- Convenient online submission

- Rigorous peer review

- Open access: articles freely available online

- High visibility within the field

- Retaining the copyright to your article

Submit your next manuscript at $\boldsymbol{\nabla}$ springeropen.com 